\title{
Studies by the U.S. Geological Survey on Sources, Transport, and Fate of Agricultural Chemicals
}

The U.S. Geological Survey's National Water-Quality Assessment (NAWQA) Program is assessing the sources, transport, and fate of chemicals applied to crops in agricultural basins across the Nation (referred to as "study units," see map, p. 3). Chemicals selected for study include nutrients (nitrogen and phosphorus) and about 50 commonly used pesti-

\section{Agricultural chemicals in water resources}

- About a half million tons of pesticides, 12 million tons of nitrogen, and 4 million tons of phosphorus fertilizer are applied annually to crops in the continental United States (Heimlich, 2003; Gianessi and Silvers, 2000).

- A small amount of these chemicals may move upward into the atmosphere, downward through the soil into ground water, or across the land into streams.

- Although progress has been made in reducing pollution from point sources and nonpoint sources (including agriculture), agriculture is the "leading source of remaining impairments in the Nation's rivers and lakes" (Heimlich, 2003).

- Concentrations of pesticides and their breakdown products are widespread in surface water and ground water across the United States. For example, at least one pesticide was found in about 97 percent of water samples and in more than 90 percent of fish samples from agricultural streams, and in nearly 60 percent of shallow wells sampled in agricultural areas (Hamilton and others, 2004). cides and their transformation products, including triazine and acetanilide herbicides such as atrazine and metolachlor, and organophosphorus insecticides such as chlorpyrifos and diazinon.

The basins in the studies represent a range of agricultural settings - with varying crop types and agricultural practices related to tillage, irrigation, artificial drainage, and chemical use-as well as a range of landscapes with different geology, soils, topography, climate, and hydrology. Consistent methodology and analysis allow comparisons among the different basins. This study design leads to an improved understanding of the many factors that can affect the movement of water and chemicals in different agricultural settings (see "Complex factors," next page).

Information from these studies will help with decision-making related to chemical use, conservation, and other farming practices that are used to reduce runoff of agricultural chemicals and sediment from fields. This information also will benefit the U.S. Environmental Protection Agency, the Department of Agriculture, local and regional water managers, and agricultural chemical manufacturers who are involved in managing chemical use and pesticide registration.

\section{Objectives of the agricultural chemicals study}

1. Quantify the amount of water and selected agricultural chemicals entering, leaving, and accumulating within the watershed (referred to as an annual "mass budget").

2. Determine rates of transport and residence times of water and chemicals in ground water, the soil zone, and in streams.

3. Assess transport and transformation of selected chemicals in different parts of the hydrologic system, as affected by natural processes, chemical properties, and agricultural management practices.

4. Develop tools and quantitative methods, such as models, to characterize the transport and fate of chemicals within the watershed, and extrapolate the findings to similar, unmonitored agricultural and environmental settings.

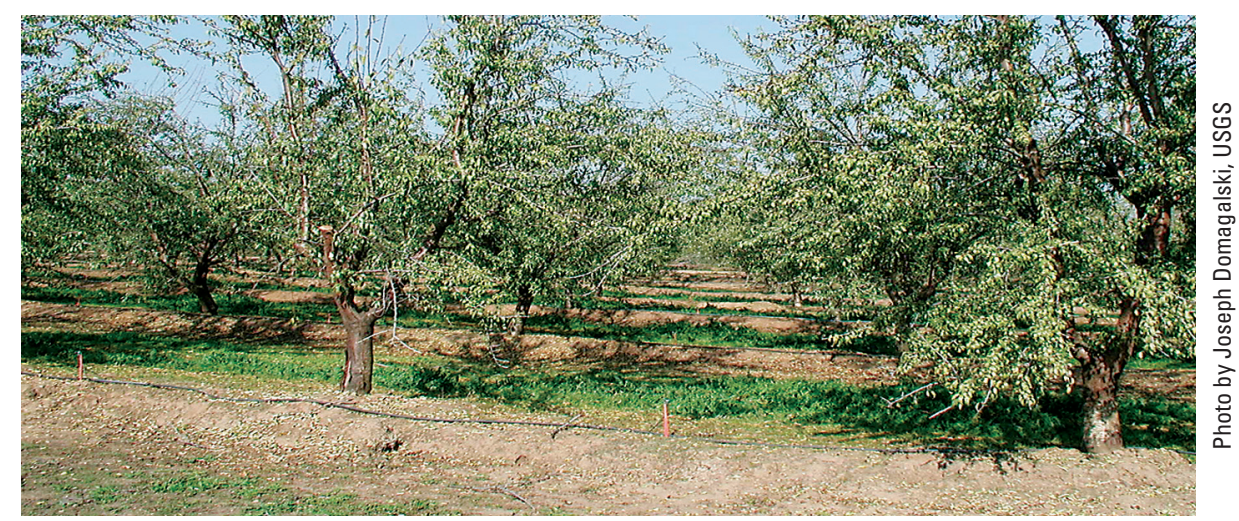

Almond orchard in the Mustang Creek watershed of the San Joaquin Valley of California. Microsprinklers deliver a gentle spray of water around the orange-colored outlets, helping to conserve water and reduce runoff of pesticides and other agricultural chemicals. 


\section{Multi-scale studies improve understanding of chemical transport}

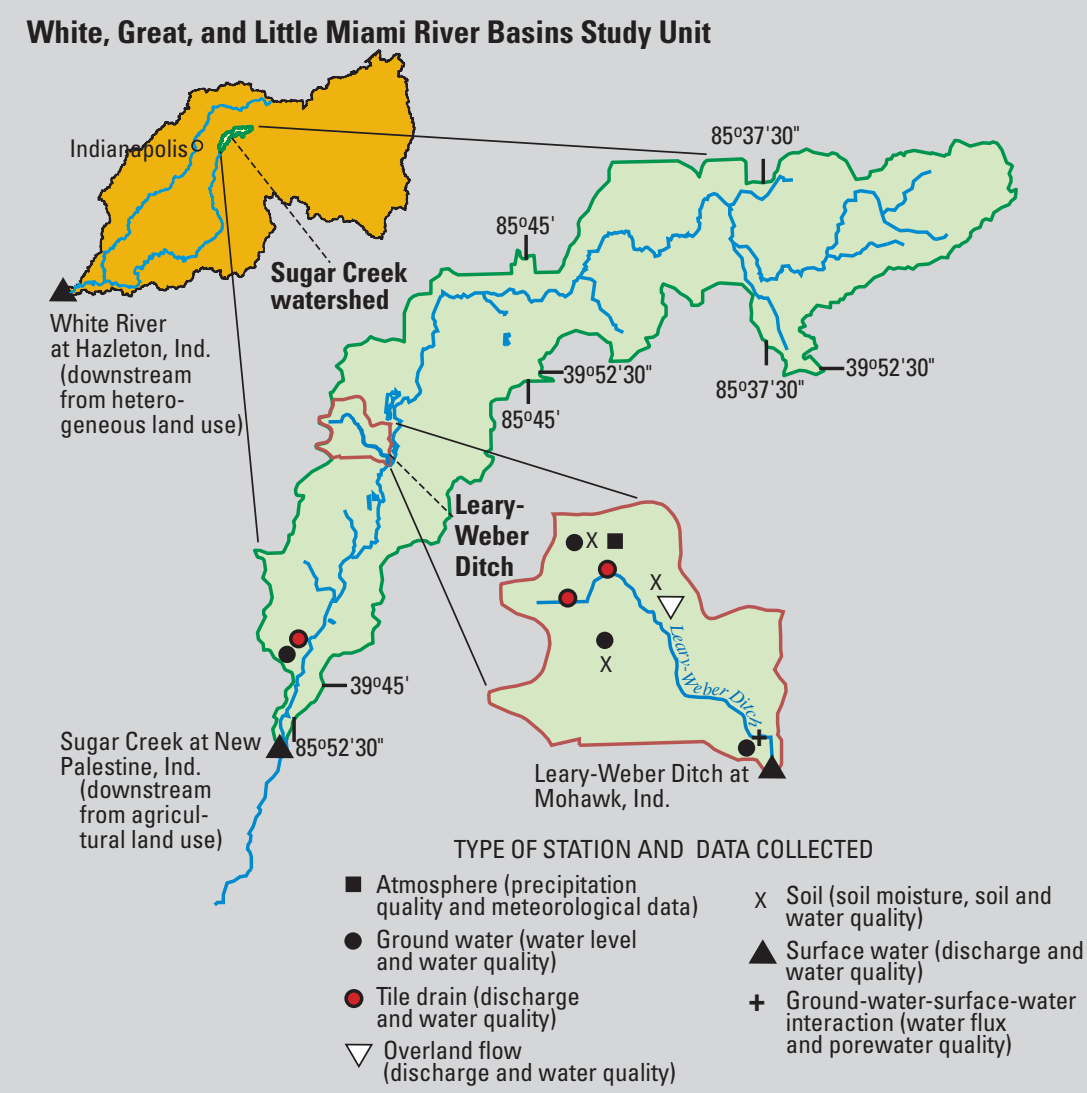

A unique feature of these studies is the simultaneous assessment of agricultural chemicals throughout the hydrologic system at many scales.

In a small sub-basin within each study unit, data are collected on precipitation, wind speed, solar radiation, and air temperature; on streamflow (discharge); on water quality in streams, runoff, tile drains and shallow ground water; and on sediment quality in the streambed and agricultural soils. Streamflow and water quality also are assessed in the larger river network of the study unit. A network of wells is sampled to characterize the age, movement, and quality of shallow ground water; in most areas, wells along a 1- to 2-mile-long flow system are used to characterize chemical transport rates and transformation processes in the shallow system recharged within about the last 50 years.

In this study area near Indianapolis, Ind., the 2.4-square-mile $\left(\mathrm{mi}^{2}\right)$ drainage area of the Leary-Weber Ditch is nested within the Sugar Creek watershed, a 95$\mathrm{mi}^{2}$ agricultural basin nested within the larger, more heterogeneous White River Basin (more than 11,000 $\mathrm{mi}^{2}$ ).

\section{Complex factors control the transport and fate of agricultural chemicals}

These USGS studies address the complex processes controlling the transport, and fate of agricultural chemicals in streams and ground water, as well as how these processes are affected by natural factors, agricultural practices, and chemical properties.

Not all of the agricultural chemicals remain in the soil or are taken up by plants; a small amount can move upward into the atmosphere, downward through the soil into shallow ground water and underlying aquifers, or across the land into streams. This movement is controlled, in part, by natural factors such as hydrogeology, climate, topography, and soils, making water resources in some basins more vulnerable to contamination than others.

For example, throughout much of the upper Midwest, large amounts of chemicals are used on corn and soybean fields, but underlying ground water generally has relatively low concentrations of agricultural chemicals because the low permeability soils and glacial till mini- mize downward movement. On that part of the Delmarva Peninsula in Maryland, ground water is more vulnerable because of permeable soils underlain by sand and gravel, which enable rapid infiltration and downward movement of water and chemicals. Streams are most vulnerable to contamination from agricultural chemicals where poorly drained soils, agricultural practices, and topography encourage the rapid movement of water off of fields, or where tile drains and ditches quickly transport agricultural runoff from fields to streams, such as in the White River Basin in Indiana.

Natural transformation processes, such as denitrification, and chemical properties play an important role in transport. For example, poorly drained and poorly oxygenated soils with organic-rich sediments can promote denitrification, which can thereby reduce nitrate concentrations entering streams.

Some chemicals, such as atrazine and nitrate, readily dissolve and move with water in both streams and aquifers, whereas many forms of phosphorus and some pesticides, such as chlorpyrifos and permethrin, attach to soil particles and are transported to streams with eroded soil, particularly during times of runoff from precipitation or irrigation. Ground water typically is less vulnerable to contamination by chemicals that strongly attach to soils.

Some chemicals, such as atrazine, are slowly transformed by natural processes and can persist in soil and water for years or even decades. Other pesticides, such as diazinon, are relatively unstable in water and break down to other compounds within days or weeks. Chemicals that persist for a long time are more likely to be transported farther than compounds that are short lived.

Chemical transport also is influenced by agricultural practices, such as methods of tillage and drainage, and chemical use. For example, farmers may leave the soil surface undisturbed from harvest to planting (referred to as "no-till"), and may plant and maintain buffer strips around fields and streams. By decreasing runoff and soil erosion, these practices also decrease chemical transport. Use of drip irrigation in lieu of furrow irrigation decreases the amount of water lost to ditches or evaporation, and allows better control of the amounts of pesticides and nutrients added to irrigation water. 


\section{Agricultural chemicals are studied in basins across the Nation}

Studies were begun in 2001 in five agricultural basins within NAWQA study units. Two more studies (gray-shaded study units in map) are scheduled to begin in 2005. As the studies progress, additional basins will likely be added. The study areas represent diverse agricultural settings, as defined by crop and animal production activities, management practices (related to chemical use, irrigation, drainage, and tillage), and hydrogeologic settings (a combination of surface and subsurface systems with characteristic climate, topography, geology, and soils).

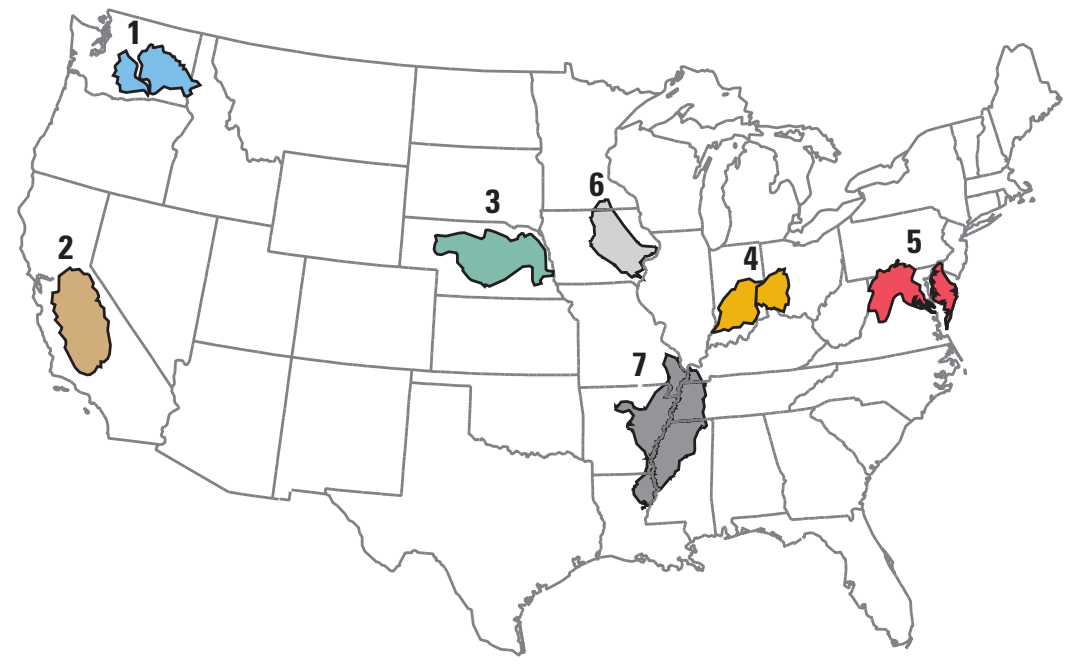

\begin{tabular}{|c|c|c|c|c|c|}
\hline & $\begin{array}{l}\text { NAWOA study unit and } \\
\text { agricultural chemicals } \\
\text { study area }\end{array}$ & $\begin{array}{l}\text { Major crops and } \\
\text { animal } \\
\text { production }\end{array}$ & $\begin{array}{c}\text { Primary agricultural } \\
\text { management practices* }\end{array}$ & Hydrogeologic setting & Major water-quality issues \\
\hline 1 & $\begin{array}{l}\text { Central Columbia } \\
\text { Plateau-Yakima River } \\
\text { Basin Study Unit } \\
\text { (Granger Drain sub-basin } \\
\text { in Washington) }\end{array}$ & $\begin{array}{l}\text { Orchards, } \\
\text { vineyards, corn, } \\
\text { hay, mixed row } \\
\text { crops; intensive } \\
\text { dairy }\end{array}$ & $\begin{array}{l}\text { Spray, furrow, and drip } \\
\text { irrigation; water delivery and } \\
\text { drainage channels; conventional } \\
\text { tillage and no-till; tile drains, } \\
\text { ditches; widespread use of } \\
\text { polyacrylamide (PAM) }\end{array}$ & $\begin{array}{l}\text { Arid; deep loess soils } \\
\text { underlain by basalt }\end{array}$ & $\begin{array}{l}\text { Pesticides and nutrients in streams, } \\
\text { drains, and ground water; water } \\
\text { temperature; sediment and fecal } \\
\text { bacteria in streams }\end{array}$ \\
\hline 2 & $\begin{array}{l}\text { San Joaquin-Tulare } \\
\text { Basins Study Unit } \\
\text { (Lower Merced River } \\
\text { and Mustang Creek } \\
\text { watershed in California) }\end{array}$ & $\begin{array}{l}\text { Orchards, } \\
\text { vineyards, mixed } \\
\text { row crops; } \\
\text { intensive dairy } \\
\text { and poultry }\end{array}$ & $\begin{array}{l}\text { Spray, furrow, flood, and drip } \\
\text { irrigation; conventional tillage } \\
\text { and no-till }\end{array}$ & $\begin{array}{l}\text { Arid; permeable } \\
\text { sands with relatively } \\
\text { shallow water tables } \\
\text { and poorly drained } \\
\text { soils with deeper } \\
\text { water tables }\end{array}$ & $\begin{array}{l}\text { Runoff from winter rains carries } \\
\text { pesticides to streams, with toxicity } \\
\text { to aquatic invertebrates; nitrate in } \\
\text { ground water in localized areas }\end{array}$ \\
\hline 3 & $\begin{array}{l}\text { Central Nebraska Basins } \\
\text { Study Unit (Maple Creek } \\
\text { watershed in Nebraska) }\end{array}$ & $\begin{array}{l}\text { Corn, soybeans, } \\
\text { alfalfa, hay, and } \\
\text { wheat; beef cattle, } \\
\text { some dairy and } \\
\text { hogs }\end{array}$ & $\begin{array}{l}\text { Mostly dryland; central pivot } \\
\text { irrigation; conventional and } \\
\text { conservation tillage, no-till } \\
\text { increasing; some tile drains }\end{array}$ & $\begin{array}{l}\text { Semiarid; permeable } \\
\text { surface and subsurface }\end{array}$ & $\begin{array}{l}\text { Herbicides and nutrients in streams } \\
\text { and ground water, including in } \\
\text { drinking-water wells; sediment in } \\
\text { streams }\end{array}$ \\
\hline 4 & $\begin{array}{l}\text { White, Great, and Little } \\
\text { Miami River Basins } \\
\text { Study Unit (Sugar Creek } \\
\text { watershed in Indiana) }\end{array}$ & $\begin{array}{l}\text { Corn and } \\
\text { soybeans; few to } \\
\text { no animals }\end{array}$ & $\begin{array}{l}\text { No irrigation; conventional and } \\
\text { reduced tillage; tile drains and } \\
\text { ditches }\end{array}$ & $\begin{array}{l}\text { Humid; poorly } \\
\text { drained soils; } \\
\text { relatively } \\
\text { impermeable glacial } \\
\text { till and sediment }\end{array}$ & $\begin{array}{l}\text { Herbicides in streams; accelerated } \\
\text { transport of pesticides and nutrients } \\
\text { to streams via tile drains }\end{array}$ \\
\hline 5 & $\begin{array}{l}\text { Potomac River Basin } \\
\text { \& Delmarva Peninsula } \\
\text { Study Unit (Morgan } \\
\text { Creek watershed in } \\
\text { Maryland) }\end{array}$ & $\begin{array}{l}\text { Corn and } \\
\text { soybeans; some } \\
\text { dairy }\end{array}$ & $\begin{array}{l}\text { Some central pivot irrigation; } \\
\text { conventional tillage and no-till }\end{array}$ & $\begin{array}{l}\text { Humid; moderately } \\
\text { to well drained soils; } \\
\text { permeable sand and } \\
\text { gravel suficial aquifer }\end{array}$ & $\begin{array}{l}\text { Herbicides in streams and ground } \\
\text { water, including drinking-water } \\
\text { wells; nitrate greater than drinking- } \\
\text { water standards in some drinking- } \\
\text { water wells }\end{array}$ \\
\hline 6 & $\begin{array}{l}\text { Eastern Iowa Basins } \\
\text { Study Unit (South } \\
\text { Fork of the Iowa River } \\
\text { watershed in Iowa) }\end{array}$ & $\begin{array}{l}\text { Corn and } \\
\text { soybeans; } \\
\text { extensive hog } \\
\text { confined feeding } \\
\text { operations }\end{array}$ & $\begin{array}{l}\text { No irrigation; conventional and } \\
\text { conservation tillage; tile drains } \\
\text { and ditches }\end{array}$ & $\begin{array}{l}\text { Humid; poorly to } \\
\text { moderately drained } \\
\text { soils from glacial till }\end{array}$ & $\begin{array}{l}\text { Herbicides and nutrients in } \\
\text { streams, transported by overland } \\
\text { flow and tile drains; potential for } \\
\text { pharmaceuticals in streams and } \\
\text { ground water from hog operations }\end{array}$ \\
\hline & $\begin{array}{l}\text { Mississippi Embayment } \\
\text { Study Unit (Bogue } \\
\text { Phalia watershed in } \\
\text { Mississippi) }\end{array}$ & $\begin{array}{l}\text { Cotton, rice, } \\
\text { soybeans, corn; } \\
\text { catfish, few other } \\
\text { animals }\end{array}$ & $\begin{array}{l}\text { Flood, pivot, spray, and furrow } \\
\text { irrigation }\end{array}$ & $\begin{array}{l}\text { Subtropical; poorly } \\
\text { drained alluvial soils }\end{array}$ & $\begin{array}{l}\text { Streams affected by residual } \\
\text { organochlorines and currently used } \\
\text { pesticides, fine sediment, and low } \\
\text { dissolved oxygen }\end{array}$ \\
\hline
\end{tabular}

*Pesticide and fertilizer use is heavy in each study area, and cattle or hog manure is applied to fields in some places. 


\section{How study results can be used}

The findings of these studies will provide a better understanding of the transport and fate of selected agricultural chemicals in various agricultural and environmental settings. This understanding will enable the development of models to extrapolate information from direct water-quality measurements to similar, yet unmonitored, agricultural areas. Farmers will gain a better understanding of how their operations affect water quality. The findings also will guide future scientific research on processes affecting transport and fate of agricultural chemicals and help water policy makers:

- Optimize selection and timing of monitoring on the basis of understanding geographic areas and water resources most likely to be affected;

- Evaluate conservation strategies such as the protection of riparian areas and buffer strips, crop management, and chemical-use management. Stakeholders associated with the U.S. Department of Agriculture and local and regional water managers will better anticipate the effectiveness and timing of these strategies for controlling transport of chemicals and sediment from fields, in streams, and within the groundwater system; and

- Improve registration and regulation of pesticides on the basis of a better understanding of their transport (including transport of breakdown products), as affected by chemical properties and natural processes.

by Paul D. Capel, Pixie A. Hamilton, and Martha L. Erwin

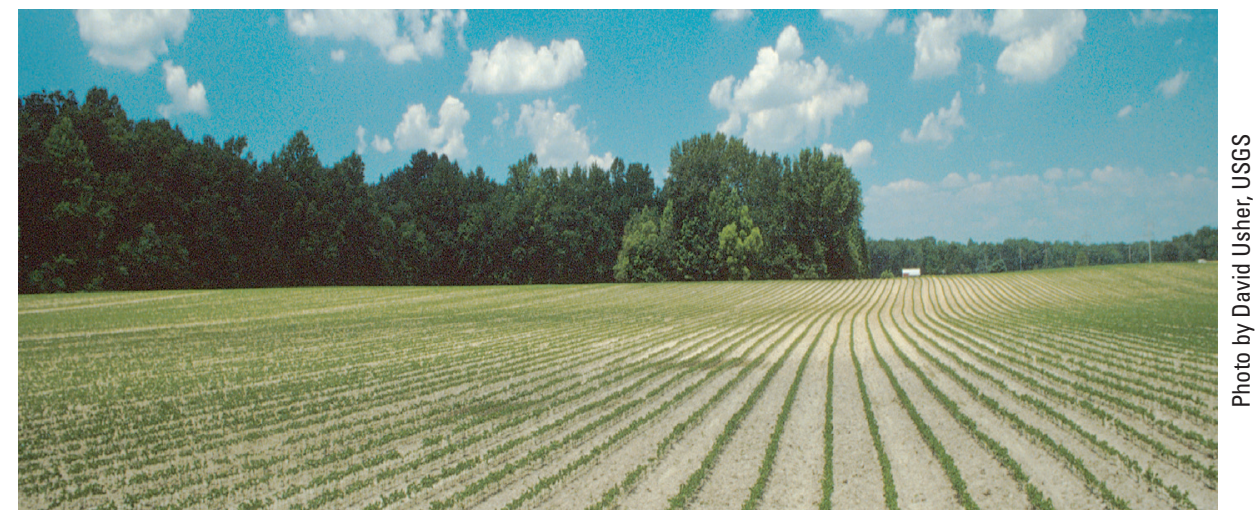

Soybean field on well-drained farmland on the Delmarva Peninsula.

\section{For additional information and questions, contact:}

Paul Capel, Team Leader

(612)625-3082 capel@usgs.gov

\section{Lead Scientists:}

Kathy McCarthy, Central Columbia Plateau-Yakima River Basin

(503) 251-3527 mccarthy@usgs.gov

Jason Vogel, Central Nebraska Basins (402) 437-5129 jrvogel@usgs.gov

Tracy Hancock, Potomac River Basin and Delmarva Peninsula (804) 261-2618 thancock@usgs.gov

Joseph Domagalski, San Joaquin-Tulare River Basins (916) 278-3077 joed@usgs.gov

Nancy Baker, White, Great, and Little Miami River Basins (317) 290-3333 ntbaker@usgs.gov

Stephen Kalkhoff, Eastern Iowa Basins (319) 358-3611 sjkalkho@usgs.gov

Richard Coupe, Mississippi Embayment (601) 933-2982 rhcoupe@usgs.gov

\section{USGS fact sheets about individual agricultural chemical studies}

http://water.usgs.gov/pubs/fs/fs08003

http://water.usgs.gov/pubs/fs/fs08103

http://water.usgs.gov/pubs/fs/fs08203

http://water.usgs.gov/pubs/fs/fs08303

http://water.usgs.gov/pubs/fs/fs08403

\section{References}

Gianessi, L.P. and Silvers, C.S., 2000, Trends in Crop Pesticide Use: Comparing 1992 and 1997: Washington, D.C., National Center for Food and Agricultural Policy, http://www.ncfap.org/ncfap/trendsreport. pdf, accessed June 3, 2004.
Heimlich, Ralph, 2003, Agricultural

Resources and Environmental Indicators, 2003: Agriculture Handbook No. (AH722): U.S. Department of Agriculture Economic Research Service http://www.ers.usda.gov/ publications/arei/ah722/, accessed May 25, 2004. [available online only]

Hamilton, P.A., Miller, T.L., and Myers, D.N., 2004: Water quality in the Nation's Streams and Aquifers-Overview of Selected Findings, 1991-2001: U. S. Geological Survey Circular 1265, 20 p. [available online at http://water.usgs.gov/pubs/circ/2004/1265/]

\section{The NAWOA Program}

The study of agricultural chemicals is one of five national priority topics being addressed by the National Water-Quality Assessment (NAWQA) Program in its second decade of studies, which began in 2001. Other topics include (1) effects of urbanization on stream ecosystems (USGS Fact Sheet 042-02); (2) ecological effects of nutrient enrichment (USGS Fact Sheet 118-03); (3) mercury in stream ecosystems (USGS Fact Sheet 016-03); and (4) transport of contaminants to public-supply wells.

During the Program's first decade (1991-2001), NAWQA scientists assessed water chemistry, stream hydrology, habitat, and biological communities in 51 major river basins (referred to as "Study Units"; a map is available at http://water.usgs.gov/nawqa). The assessments characterize the ambient water resource - the source of about 60 percent of the Nation's drinking water and water for industrial, irrigation, and recreational uses. During its first decade, NAWQA made baseline assessments of pesticides, nutrients, volatile organic compounds, trace elements, dissolved solids, and radon, as well as the condition of aquatic habitats and fish, insect, and algal communities. These findings are described in hundreds of reports, which can be accessed at the NAWQA Web site above.

In the second decade of studies, 42 of the 51 study units are planned to be reassessed to determine trends at many of the streams and ground-water monitoring sites; to fill critical gaps in the characterization of water-quality conditions; and to build upon earlier NAWQA findings that show how natural features and human activities affect water quality and aquatic ecosystems. 